\title{
SERIES
}

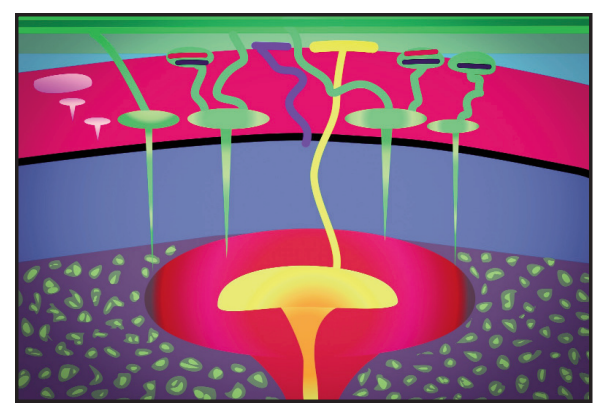

Igneous Rock

Associations 16.

The Late Permian

Emeishan Large lgneous Province

\section{J. Gregory Shellnutt}

Department of Earth Sciences

National Taiwan Normal University

88 Tingzhou Road Section 4

Taipei 11677, Taiwan

E-mail:jgshelln@ntnu.edu.tw

\section{SUMMARY}

The Late Permian Emeishan large igneous province (ELIP) covers $\sim 0.3 \mathrm{x}$ $10^{6} \mathrm{~km}^{2}$ of the western margin of the Yangtze Block and Tibetan plateau of SW China with displaced, correlative units in northern Vietnam (Song Da zone). The ELIP is of particular interest because it contains numerous world-class base metal deposits and is contemporaneous with the Late Capitanian mass extinction. The flood basalts are the signature feature of the ELIP but there are also picritic and silicic volcanic rocks and layered mafic-ultramafic and silicic plutonic rocks exposed. The ELIP is divided into three zones (i.e. inner, middle and outer) which correspond to a decrease in crustal thickness from the inner to the outer zone. The eruptive age of the ELIP is $\sim 260 \mathrm{Ma}$ and is constrained by paleomagnetic observations to an interval of $\leq 3$ m.y. The presence of picritic and basaltic volcanic rocks is evidence for a high temperature regime; however, it is uncertain if these magmas were derived from subcontinental lithospheric mantle or sublithospheric mantle (i.e. asthenosphere or mantle plume) sources or both. The range of $\operatorname{Sr}\left(\mathrm{I}_{\mathrm{Sr}} \approx 0.7040\right.$ to 0.7132$)$, $\mathrm{Nd}\left(\varepsilon \mathrm{Nd}_{(\mathrm{T})} \approx-14\right.$ to +8$), \mathrm{Pb}$ $\left({ }^{206} \mathrm{~Pb} /{ }^{204} \mathrm{PbPb}_{\mathrm{I}} \approx 17.9\right.$ to 20.6$)$ and $\mathrm{Os}$ $(\gamma \mathrm{Os} \approx-5$ to +11$)$ isotope values of the ultramafic and mafic rocks does not permit a conclusive answer to source origin but it is clear that some rocks were affected by crustal contamination. However, the identification of depleted isotope compositions suggests that there is a sub-lithospheric mantle component in the system. The ELIP is considered to be a mantle plume-derived large igneous province and may have contributed to ecosystem collapse during the latest Capitanian.

\section{SOMMAIRE}

La grande province ignée d'Emeishan de la fin du Permien (ELIP) s'étend sur environ $0,3 \times 10^{6} \mathrm{~km}^{2}$ à la marge ouest du bloc Yangtze et du plateau tibétain du sud-ouest de la Chine, avec des unités corrélatives déplacées dans le nord du Vietnam (zone de Song Da). L'ELIP est intéressant parce qu'il renferme de nombreux gisements de métaux de base de classe mondiale et qu'il est contemporain de l'extinction de masse de la fin du Capitanien. Les basaltes de plateau sont la signature géologique de l'ELIP, bien qu'on y rencontre aussi des roches volcaniques picritiques et siliciques ainsi que des formations stratifiées de roches mafiques à ultramafiques et plutoniques acides. L'ELIP est divisé en trois zones (interne, médiane et externe) correspondant à une diminution de l'épaisseur crustale de la zone interne vers la zone externe. L'éruption de l'ELIP date d'environ $260 \mathrm{Ma}$ mais les observations paléomagnétiques limitent sa durée à $\leq 3$ m.a. La présence de roches volcaniques picritiques et basaltiques indique un régime à haute température mais on ne sait pas si ces magmas proviennent de sources mantelliques lithosphériques sous-continentales ou sous-continentales mantelliques (c.-à-d. asthénosphère ou panache mantellique) ou des deux. La gamme des valeurs isotopiques $\mathrm{Sr}\left(\mathrm{I}_{\mathrm{Sr}}\right.$ $\approx 0,7040$ à 0,7132$), \mathrm{Nd}\left(\varepsilon \mathrm{Nd}_{(\mathrm{T})} \approx-14\right.$ à $+8), \mathrm{Pb}\left({ }^{206} \mathrm{~Pb} /{ }^{204} \mathrm{PbPbI} \approx 17,9\right.$ à 20,6$)$ et Os $(\gamma \mathrm{Os} \approx-5$ à +11$)$ des roches ultramafiques et mafiques ne permet pas de décider de l'origine de la source mais il est clair que certaines roches ont subis de contaminations crustales. Cependant l'existence de compositions isotopiques appauvries indique la présence dans le système d'une composante mantellique sous-lithosphérique. L'ELIP est considéré comme une grande province ignée dérivée d'un panache mantellique qui pourrait bien avoir contribué à l'effondrement de l'écosystème à la toute fin du Capitanien.

\section{INTRODUCTION}

The Late Permian Emeishan large 
igneous province (ELIP) is a relatively small, continental mafic large igneous province but is the focus of a tremendous amount of geological, geochemical, paleomagnetic, geochronological and biostratigraphic research since the 1980s. In spite of its stature as a 'smaller' large igneous province, the ELIP is an important geological feature of SW China, not only because it hosts a number of $\mathrm{Fe}-\mathrm{Ti}-\mathrm{V}$ oxide and $\mathrm{Ni}-\mathrm{Cu}-$ (PGE) sulphide deposits, but is also contemporaneous with the latest period of the Late Capitanian-Early Wuchiapingian mass extinction (i.e. end-Guadalupian) indicating that there may be a link between the two (Zhou et al. 2002a; Ganino and Arndt 2009; Sun et al. 2010; Shellnutt et al. 2012). Beyond the economic and biogeological significance, the ELIP contains a diverse set of volcanic and plutonic igneous rocks (i.e. picrite, basalt, layered gabbroic intrusions, basaltic andesite, andesite, trachyte, rhyolite, syenite, and granite). The fact that the magmatic plumbing system of the ELIP is well exposed at the surface is relatively special because plutonic and hypabyssal rocks of LIPs are not often observed together. The bulk of the geological and petrological research, including evidence of structural doming of the crust, suggests that the ELIP formed by a mantle plume. Consequently, it is considered to be one of the best examples of a mantle plumederived LIP and is used as a benchmark for comparison with other continental mafic LIPs (Campbell 2005).

There are some widely accepted ideas on the formation of the ELIP (e.g. mantle plume-derived) but recently many older interpretations (e.g. evidence for uplift) are giving way to new and alternative ideas. There are ongoing debates regarding the source of the flood basalts, the formation of the oxide-ore deposits and whether crustal doming occurred prior to volcanism (Xu et al. 2001, 2004; Song et al. 2001; He et al. 2003; Zhou et al. 2005; Utskins Peate and Bryan 2008; Sun et al. 2010; Zhong et al. 2011, Shellnutt and Jahn 2011; Kamenetsky et al. 2012).

The objective of this review paper is to introduce the salient features of the ELIP and provide a general synthesis of its formation. The paper is divided into six principal sections which focus on a specific aspect of the ELIP. The first section

describes the geological background of the ELIP, including its size, shape and zonation. The second section discusses the age of the ELIP and the duration of magmatism. The third section primarily describes and discusses the magmatic rocks which are unrelated to mineral deposits (i.e. picrite, basaltic and silicic volcanic and plutonic rocks). The fourth section discusses some of the structural features of the ELIP (i.e. crustal doming) that are interpreted to be evidence for a mantle plume and the effect that it may have had on the late Capitanian ecosystem. The fifth section describes the layered gabbrohosted $\mathrm{Ni}-\mathrm{Cu}-(\mathrm{PGE})$ sulphide and $\mathrm{Fe}-\mathrm{Ti}-\mathrm{V}$ oxide deposits. The final section presents a general synthesis of the ELIP.

\section{GEOLOGICAL BACKGROUND}

The ELIP is located on the western edge of the Yangtze Block near the boundary with the Songpan-Ganze terrane (Figs. 1 and 2). The wedge-shaped distribution of ELIP rocks is related to Mesozoic faulting associated with the formation of the Songpan-Ganze terrane and the Cenozoic India-Eurasian collision (Chung and Jahn 1995; Chung et al. 1997). The ELIP covers an area of at least $0.3 \times 10^{6} \mathrm{~km}^{2}$ of SW China and northern Vietnam (Song Da zone) and is subdivided into three roughly concentric zones (i.e. inner, intermediate and outer) which correspond to crustal thickness estimates (Fig. 2a, b). The centre of the ELIP is known as the inner zone and has the thickest crust which progressively thins from the intermediate to outer zone (Zhong et al. 2002; Xu et al. 2004; Zhou et al. 2005). The volcanic successions range in thickness from 0.1 to $5.0 \mathrm{~km}$ and consist mostly of flood basalts with picrite in the lower half and basaltic andesite and silicic volcanic rocks in the upper half. The volcanic rocks erupted at equatorial latitudes of eastern Pangaea on top of middle Permian limestone or directly on Precambrian cratonic rocks of the Yangtze Block. The ELIP is an important host of $\mathrm{Ni}-\mathrm{Cu}-(\mathrm{PGE})$ sulphide and $\mathrm{Fe}-\mathrm{Ti}-\mathrm{V}$ oxide mineral deposits. The inner zone, chiefly the Panxi region, contains many giant orthomagmatic $\mathrm{Fe}-\mathrm{Ti}-\mathrm{V}$ oxide deposits, whereas $\mathrm{Ni}-\mathrm{Cu}-(\mathrm{PGE})$ and PGE deposits are found within the inner and outer zones but none have been found within the intermediate zone yet (Shellnutt 2014).

\section{AGE AND DURATION OF ELIP MAGMATISM}

The sedimentology and biostratigraphy constrain the eruption of the Emeishan flood basalts to the late Permian (He et al. 2007; Sun et al. 2010). The Emeishan basalts erupted onto the Middle Permian fusulinid-bearing Neomisellina-Yabeina zone of the Maokou Limestone Formation which indicates they erupted no earlier than 263 $\mathrm{Ma}$ (He et al. 2003). The deposition of the Xuanwei Formation at $257 \pm 4 \mathrm{Ma}$ marks the end of subaerial volcanism in the region suggesting that it lasted $\leq$ 10 million years (He et al. 2007). Paleomagnetic data collected from basalt sections show evidence for an early period of normal magnetic polarity followed by reverse polarity coinciding within one normal polarity episode (i.e. $\leq 1.5 \mathrm{~m}$.y.) thereby reducing the likely eruption duration to $<3$ m.y. (Ali et al. 2005; Zheng et al. 2010). However, the radiometric ages of all magmatic rocks reveals a more complicated scenario. Over 70 published radiometric age dates have been measured by ${ }^{40} \mathrm{Ar} /{ }^{39} \mathrm{Ar}$ (11) and U/Pb (65) methods on volcanic and plutonic rocks of the ELIP and they range from $\sim 236 \mathrm{Ma}$ to $\sim 266$ Ma (Fig. 3). The range of dates may, in fact, be an artifact of different radiometric methods used (c.f. Shellnutt et al. 2012), misinterpreting rocks, poor data processing and the rock type (i.e. volcanic vs. plutonic). The first high precision zircon $\mathrm{U} / \mathrm{Pb}$ chemical abrasion ID-TIMS geochronology results from a suite of diabase dykes and granitic rocks yielded ages between $257.6 \pm 0.5 \mathrm{Ma}$ and $259.6 \pm 0.5 \mathrm{Ma}$ and currently is the best emplacement age available for the ELIP (Shellnutt et al. 2012).

\section{MAGMATIC ROCKS OF THE ELIP}

Mafic continental large igneous provinces represent the physical and chemical transfer of material from the mantle to the crust and are related to lithospheric thinning and/or a mantle plume (Coffin and Eldholm 1994; 


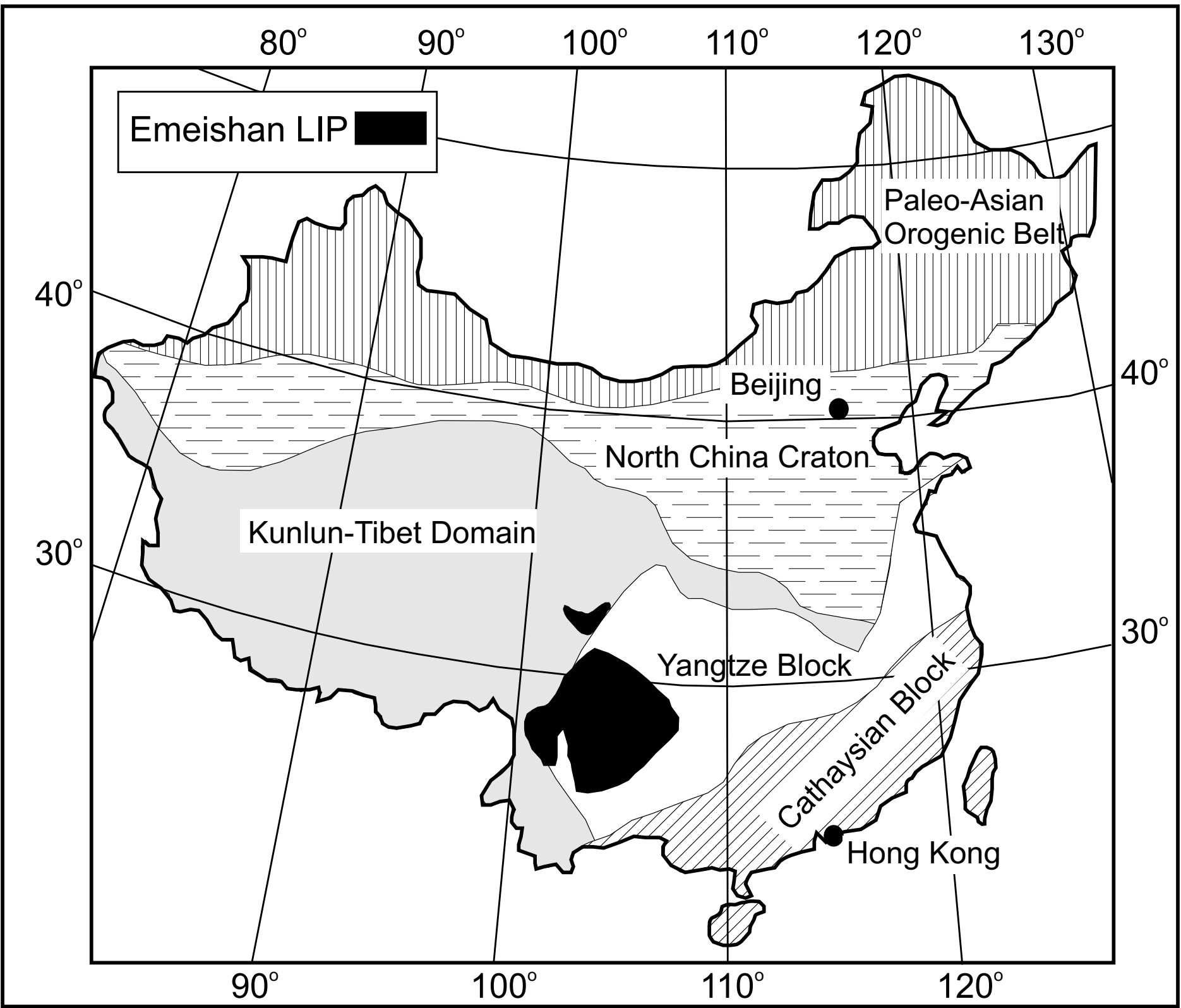

Figure 1. Major tectonic divisions of China and the location of the Emeishan large igneous province (ELIP).

Bryan and Ernst 2008). A number of geological, geochemical and thermal criteria indicate whether a given LIP was generated by a mantle plume. The main geological features associated with a mantle plume-derived LIP includes: short duration of magmatism (e.g. $\leq 1$ m.y.), the eruption of ultramafic lava, thermal anomalies, voluminous flood basalt and doming of the crust (Campbell 2007). Some of the criteria are difficult to assess, in particular the eruption duration and doming of the crust. The ELIP is considered to be a mantle plume-derived large igneous province and exhibits, to varying degrees, the criteria outlined for mantle plume-LIPs (Xu et al. 2004:

Xiao et al. 2004; Hou et al. 2006;

Kamenetsky et al. 2012). This section summarizes the magmatic features of the ELIP.

\section{Ultramafic Volcanic Rocks}

High temperature ultramafic volcanic rocks are recognized within the inner zone of the ELIP (Hanski et al. 2004, 2010; Hou et al. 2006; Zhang et al. 2006; Wang et al. 2007; Ali et al. 2010; He et al. 2010; Kamenetsky et al. 2012). There are also correlative units, including picrite, in the Song Da zone of northern Vietnam which was translated by $\sim 600 \mathrm{~km}$ sinistral offset dur- ing the Paleogene activation of the Ailao Shan-Red River fault system (Chung et al. 1997). The picritic rocks contain between 14 wt. $\%$ and 27 wt. $\%$ $\mathrm{MgO}$ but, in some cases, their composition and textures (i.e. spinifex) bear some resemblance to the komatiite of Gorgona Island (Hanski et al. 2004; Kamenetsky et al. 2012). The picrite layers are found no higher than the lower half of the volcanic succession which suggests they were amongst the earliest eruptive rocks (Xu et al. 2001; Hanski et al. 2004; Zhang et al. 2006; Li et al. 2010). The eruption and mantle potential temperatures $\left(T_{\mathrm{p}}\right)$ of the ELIP picrite layers have been estimat- 


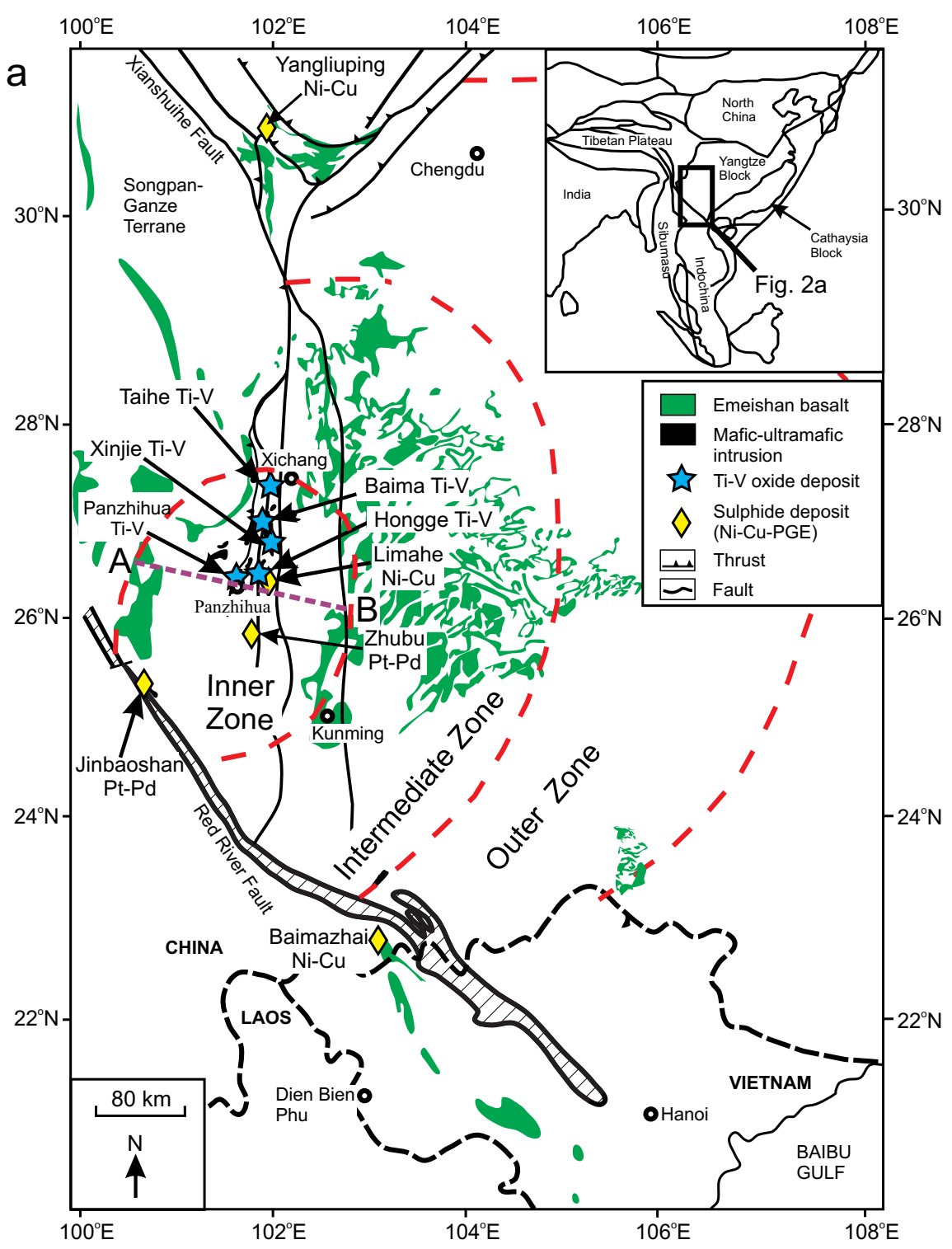

b A

Lijiang

B

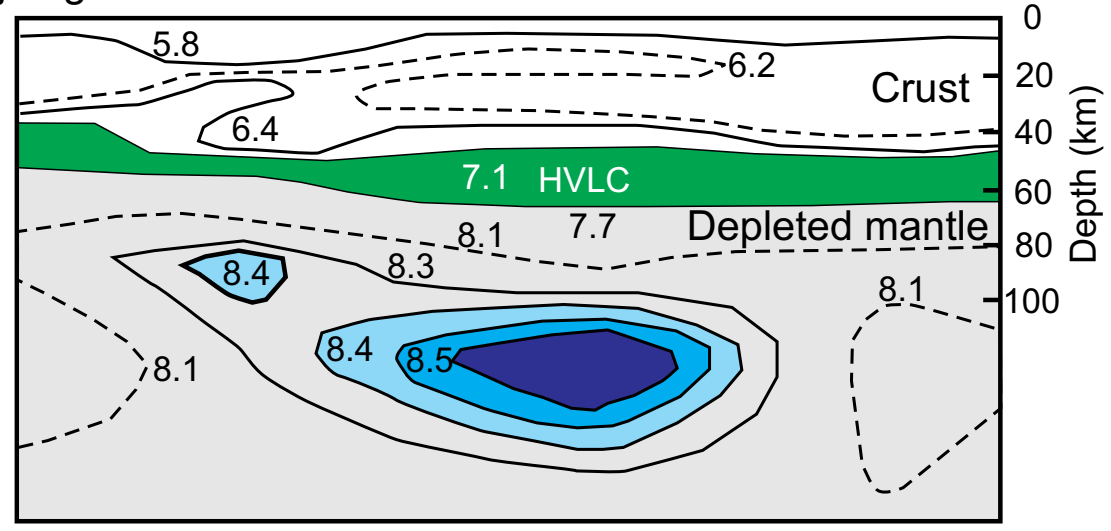

Figure 2. (a) Regional distribution of the Emeishan large igneous province (ELIP) showing the concentric zones (dashed red lines) of the ELIP and location of Ti-V oxide and $\mathrm{Ni}-\mathrm{Cu}-\mathrm{PGE}$ sulphide deposits. (b) Seismic P-wave velocity $(\mathrm{km} / \mathrm{s})$ structure of the lower crust and upper mantle beneath the western Yangtze Block. The profile is from Lijiang (A) to Zhehai (B) (modified from Xu et al. 2004). HVLC $=$ high velocity lower crust.

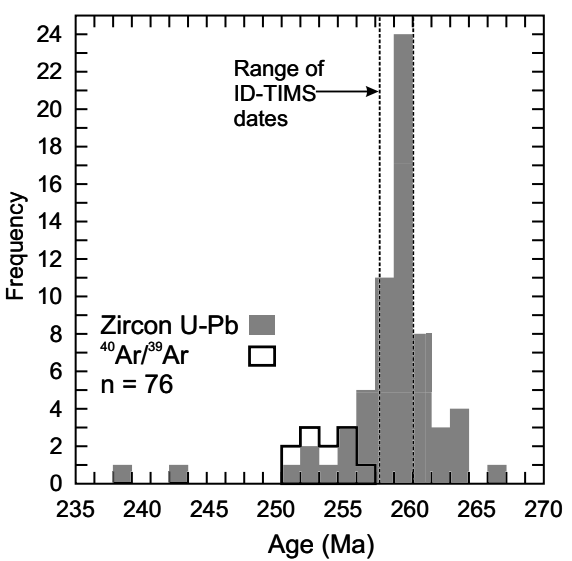

Figure 3. Frequency distribution of whole rock ${ }^{40} \mathrm{Ar} /{ }^{39} \mathrm{Ar}$ and zircon $\mathrm{U} / \mathrm{Pb}$ radioisotopic age dates of rocks from the Emeishan large igneous province (ELIP).

ed using different techniques but calculated temperatures are consistently $>$ $1540^{\circ} \mathrm{C}$ which is at least $150^{\circ} \mathrm{C}$ above the Tp estimates of primitive MORB (Xu et al. 2001; Ali et al. 2010; He et al. 2010).

The ultramafic rocks erupted relatively early, consist of 'low-Ti' and 'high-Ti' varieties, are high temperature melts, and represent a large (i.e. $>$ $20 \%$ ) amount of melting from a garnet-bearing mantle source (Hanski et al. 2004, 2010; Zhang et al. 2006; Wang et al. 2007; Kamenetsky et al. 2012). However, there are different interpretations regarding the nature of their source. The prevailing view is that the ultramafic rocks are pristine primitive melts from the starting plume-head that were modified, in some cases, via interactions with one of, or a combination of crustal material and lithospheric mantle melts and assimilation-fractional crystallization (AFC) processes (Hanski et al. 2004, 2010; Zhang et al. 2006; Wang et al. 2007; Li et al. 2010; He et al. 2010). Some of the picrite shows the most depleted $\mathrm{Sr}-\mathrm{Nd}-\mathrm{Os}$ isotope signatures (i.e. $\mathrm{I}_{\mathrm{Sr}} \approx 0.7040$; $\left.\varepsilon \mathrm{Nd}_{(\mathrm{T})} \approx+8 ; \gamma \mathrm{Os} \approx+11\right)$ in the entire ELIP and implies there is a depleted mantle-like (i.e. sub-lithosphere) component in the source (Hanski et al. 2004; C. Li et al. 2010; J. Li et al. 2012). Kamenetsky et al. (2012) have suggested that the two series (i.e. high-Ti and low-Ti) of picrite were derived from separate mantle sources; a peridotite source for the low-Ti series and a gar- 
net pyroxenite for the high-Ti series, and originated from the subcontinental lithospheric mantle which may be composed of variable proportions of eclogite, garnet pyroxenite and peridotite rather than a deep-seated mantle plume source or asthenospheric source.

\section{The Emeishan Flood Basalts}

The early themes of Emeishan basalt studies focused on their division into high- and low-Ti groups and their spatial-temporal distribution (Xu et al. 2001; Song et al. 2001; Xiao et al. 2004; He et al. 2010; Lai et al. 2012). The division into 'high-Ti' and 'low-Ti' groups corresponded to a petrological distinction as the 'high-Ti' (i.e. $\mathrm{TiO}_{2}>$ $2.5 \mathrm{wt} . \%$ ) basalts are considered to be derived by low degrees $(<8 \%)$ of partial melting of the pristine source, whereas the 'low-Ti' basalts (i.e. $\mathrm{TiO}_{2}$ $<2.5 \mathrm{wt} . \%$ ) are considered to be derived from either the subcontinental lithospheric mantle (SCLM) or picritic magmas that assimilated upper crust (Fig. 4) (Xiao et al. 2004; Wang et al. 2007; Fan et al. 2008; Song et al. 2008; Zhou et al. 2008; Qi et al. 2010). The significance of the basalt groups is that the composition is indicative of the type of mineral deposit (i.e. sulphide or oxide) which may be present in the immediate area (Zhou et al. 2008; Song et al. 2009; Wang et al. 2011). The intrusive equivalents of the basalts are often associated with mineral deposits and have textures indicative of cumulus textures; consequently, they will be discussed with the orthomagmatic deposits. Initial interpretations of the geographic distribution of the basalts from the inner and outer zones suggested that there is a consistent spatial, temporal and chemical relationship, where the 'higher-Ti' basalts are located mostly in the outer zone and the 'lower-Ti' basalts are located mostly in the inner zone (Xu et al. 2001). Furthermore, it was thought that the 'lower-Ti' basalts erupted before the 'high-Ti' basalts. The spatial-compositional variation is debatable and may not exist. For example, there are stratigraphic profiles within the inner zone that have basal 'high-Ti' basalt flows, whereas 'lower-Ti' basalts are identified within the outer zone (Shellnutt 2014).

The Emeishan basalts range in
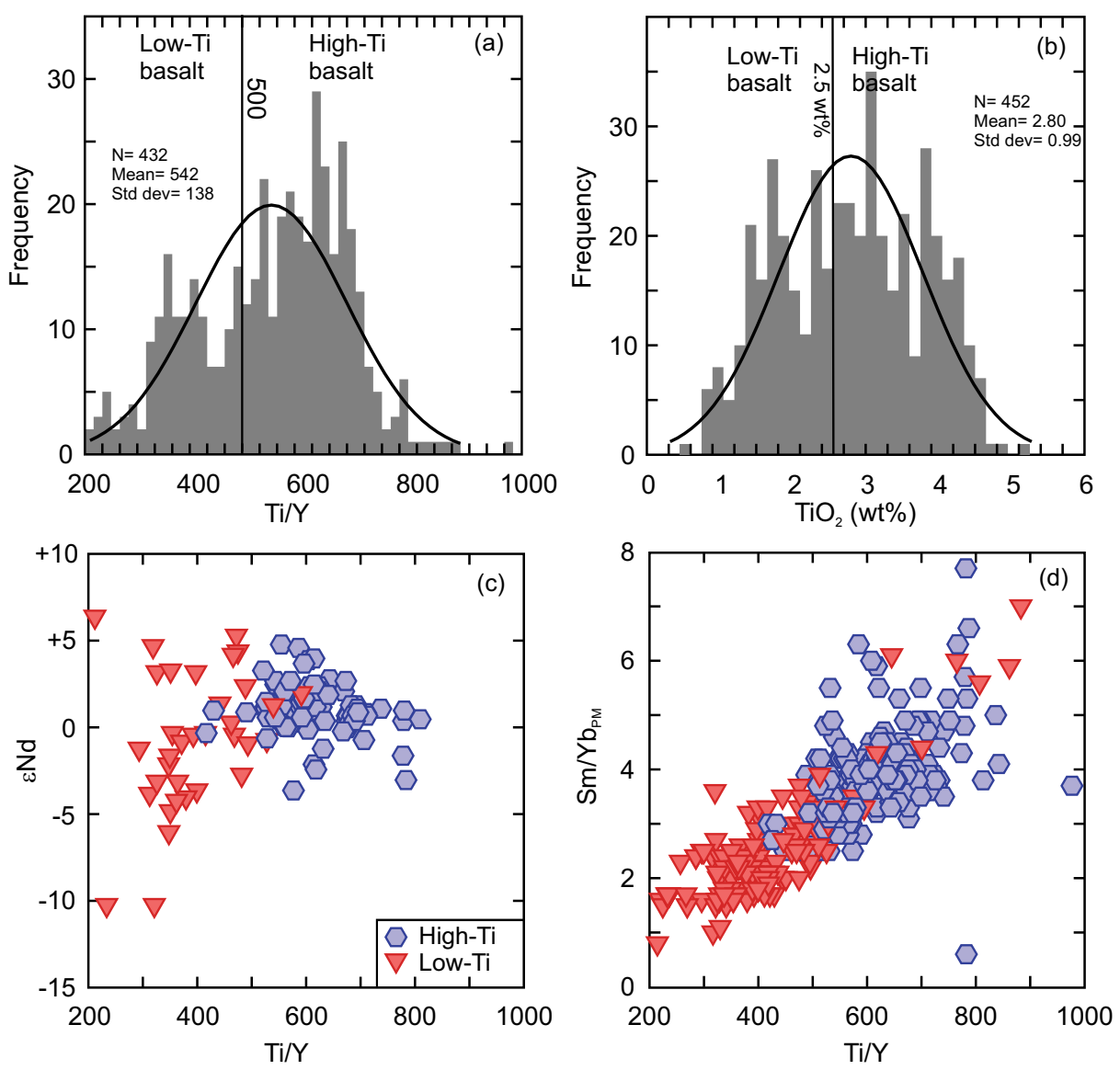

Figure 4. Frequency distribution plots of (a) Ti/Y showing the 500 division line and (b) $\mathrm{TiO}_{2}$ (wt.\%) showing the $2.5 \mathrm{wt} . \%$ division. (c) Range of $\varepsilon \mathrm{Nd}$ vs. $\mathrm{Ti} / \mathrm{Y}$ and (d) $\mathrm{Sm} / \mathrm{Yb}$ ratio vs. Ti/Y of the Emeishan basalts showing a continuous trend.

composition from subalkaline to alkaline (Fig. 5a). The whole rock Sr and $\mathrm{Nd}$ isotopes of the Emeishan basalts indicate that they could be derived from a heterogeneous mantle source and/or experienced variable degrees of crustal assimilation (Figs. 5d, 6a). The typical range of the $\varepsilon \mathrm{Nd}_{(\mathrm{T})}$ values of the Emeishan basalts is between -5 and +6 as both the 'high-Ti' basalts (i.e. $\varepsilon \mathrm{Nd}_{(\mathrm{T})}=-3.6$ to +4.8 ) and the 'low-Ti' basalts (i.e. $\varepsilon \mathrm{Nd}_{(\mathrm{T})}=-14.2$ to +6.4 ) completely overlap. Isotope data and trace elements can usually distinguish between possible source contributions but in the case of the ELIP they are not particularly insightful because of the large range in values (i.e. $\mathrm{I}_{\mathrm{Sr}} \approx 0.7040$ to $0.7132 ; \gamma \mathrm{Os} \approx-5$ to $+11 ;{ }^{206} \mathrm{~Pb} /{ }^{204} \mathrm{PbPb}_{1} \approx 17.9$ to 19.7 ) (Fig. 6). Trace elements are no more or less useful as there is a continuous compositional range across all of the basalts (i.e. 'high- and low-Ti') and the chemical trends attributed to crustal assimilation may in fact represent mix- ing between a subducted sediment component (e.g. global subducting sediments - GLOSS) and the mantle source (Fig. 5b, c, d).

The chemical diversity of the Emeishan basalts may also reflect the influence of magmatic rocks from an earlier period. During the Neoproterozoic $(\sim 800 \mathrm{Ma})$ there was an active continental margin located in the same place as the ELIP (Zhou et al. 2002b). It is possible that underplated mafic rocks from the arc magmatism served as a source or acted as a contaminant for some Emeishan magmas. Therefore the ELIP basaltic magmas could be derived from a 'pristine' mantle source (i.e. mantle plume), and/or a lithospheric mantle source and/or melting of mafic crustal rocks. In addition to the multiple sources of the basaltic magmas, they likely experienced shallow level crustal assimilation and fractional crystallization, and reflect differences in the amount of source melting. Constraining the pre- 

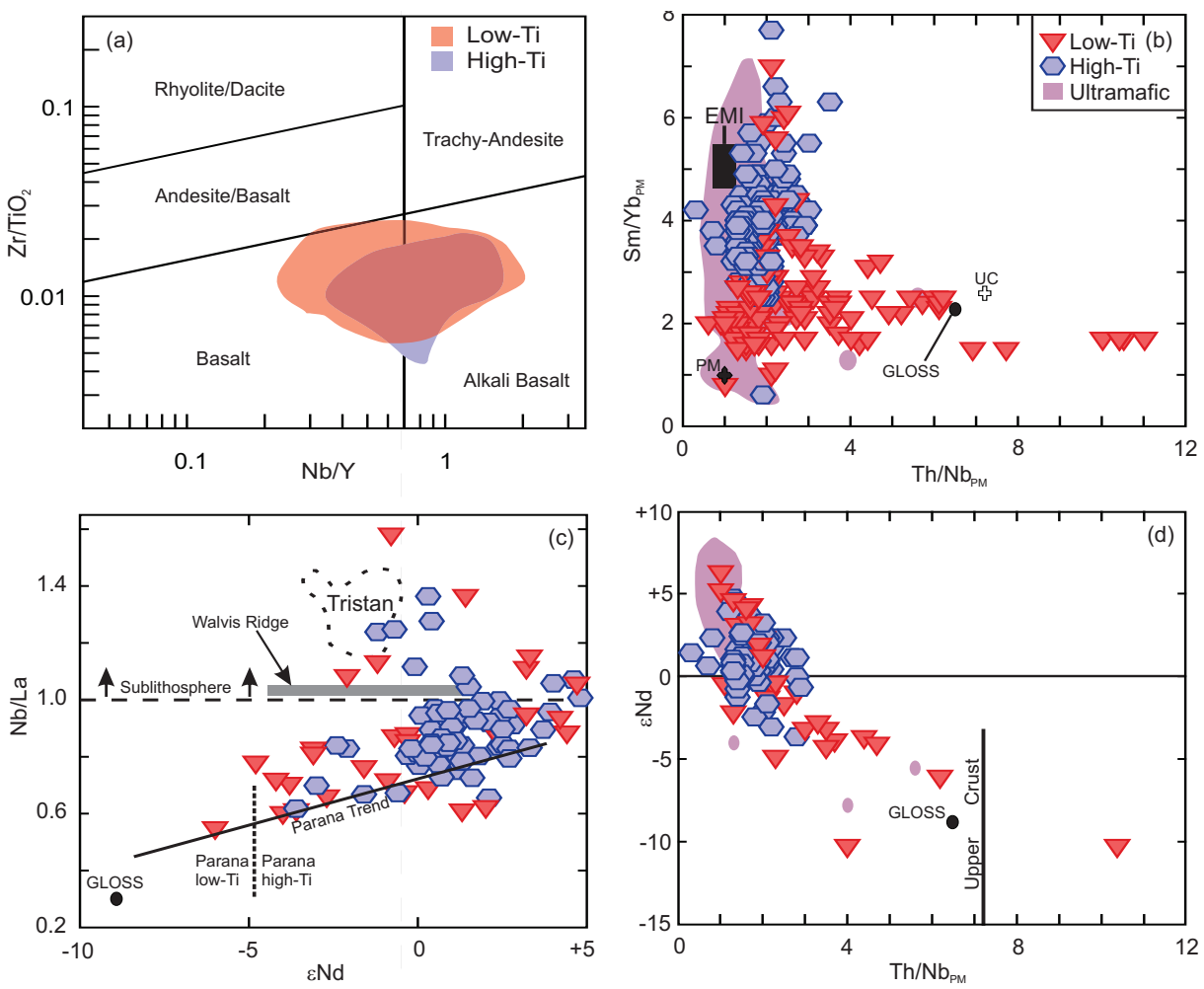

Figure 5. (a) Comparison of the Emeishan basalts using the discriminating parameters of Winchester and Floyd (1977). (b) $\mathrm{Sm} / \mathrm{Yb}_{\mathrm{PM}}$ vs. Th/ $\mathrm{Nb}_{\mathrm{PM}}$ of the basaltic rocks of the ELIP. (c) $\mathrm{Nb} / \mathrm{La}$ versus $\varepsilon N d$ of the Emeishan basalts showing the trend of the Parana basalts for comparison. (d) $\varepsilon \mathrm{Nd}$ vs. Th/ $\mathrm{Nb}_{\mathrm{PM}}$ of the basaltic and picritic rocks of the ELIP. PM = Primitive mantle normalized to values of Sun and McDonough (1989). EMI (enriched mantle I) range taken from Zindler and Hart (1986). GLOSS (global subducting sediment) values taken from Plank and Langmuir (1998) and Chauvel et al. (2008). UC = upper crust, MC = middle crust values of Rudnick and Gao (2003).

cise source characteristics and influence of crustal material on the composition of the flood basalts remains an important issue.

\section{Silicic Rocks}

The silicic volcanic and plutonic rocks of the ELIP are volumetrically minor (i.e. $\leq 5 \%$ ) components but testify to the diversity of magmas that were produced. In general, the silicic volcanic rocks are exposed in the upper portions of the volcanic stratigraphy, whereas the plutonic rocks have intruded the basement rocks of the Yangtze Block and also have intruded the lowermost flows of the flood basalts. The ELIP is an excellent region to study within-plate silicic rocks because both the volcanic and plutonic rocks are well exposed.

The silicic rocks classify as andesite, trachyandesite, trachyte, rhyolite, ignimbrite, granite and syenite and have peraluminous, metaluminous and peralkaline compositions ( $\mathrm{Xu}$ et al. 2010; Anh et al. 2011; Shellnutt et al. 2011a, b). Geochemical modelling indicates that the peralkaline rocks are derived by fractional crystallization of mafic magmas resembling the 'high-Ti' Emeishan basalt with minimal, if any, crustal assimilation (Xu et al. 2010; Shellnutt et al. 2011a, b). The peraluminous rocks are considered to be derived almost exclusively from crustal sources, although Anh et al. (2011) suggested that some peraluminous volcanic rocks were derived by extensive fractionation of 'high-Ti' basaltic magma with crustal assimilation. In contrast, the formation of the metaluminous rocks is a little more complicated as some were derived by basalt-crust AFC (assimilation-fractional crystallization) processes, whereas others were derived by partial melting of basaltic underplated rocks relat- ed to ELIP (Shellnutt and Zhou 2007; Xu et al. 2008; Shellnutt et al. 2011b).

\section{STRUCTURAL FEATURES AND ECOLOGICAL IMPACT OF THE ELIP}

\section{High Velocity in the Crust}

Perhaps one of the most intriguing interpretations in support of the ELIP mantle plume model is the presence of high seismic velocity layers within the Yangtze Block beneath the region considered to be the epicentre of magmatism (i.e. inner zone). The inner zone is shown to have thicker average crust than the middle and outer zones (Xu et al. 2004). The interpretation is that the deep (i.e. $>100 \mathrm{~km}$ ) high seismic velocity layers represent the 'fossilized' mantle plume head, whereas the lower crust (i.e. $40-60 \mathrm{~km}$ ) high velocity layers represent underplated mafic and ultramafic rocks that were injected into the lower crust and fed the surface flows and shallow crustal intrusions (Fig. 2b). The seismic data interpretation is a compelling argument in favour of the ELIP mantle plume model but the same region experienced an older (i.e. $\sim 800 \mathrm{Ma}$ ) period of continental arc magmatism. Therefore, it is possible that the older arc-related magmas were also preserved in the lower crust; however, they cannot be distinguished from the younger ELIP-related material and thus the crustal seismic velocity layers may consist of rocks derived from two separate periods of magmatism.

\section{Flexure of the Crust}

It is theorized that excessive heat (i.e. $100^{\circ} \mathrm{C}$ to $350^{\circ} \mathrm{C}$ above ambient conditions) from a mantle plume is suitable to induce maximum uplift of the surface directly beneath the plume head to an area within a $200 \mathrm{~km}$ radius (Campbell 2005). The amount of vertical displacement may be in excess of $\sim 1 \mathrm{~km}$ (Campbell 2005). The ELIP is considered to be one of the best examples of mantle plume-induced surficial uplift and doming (Campbell 2005, 2007). The progressive thickening of the Maokou Limestone from the inner zone to the outer zone of the ELIP is interpreted as evidence for uplift related to a mantle plume (He et al. 2003) (Fig. 7). However, the uplift model for the ELIP has come under scrutiny and 

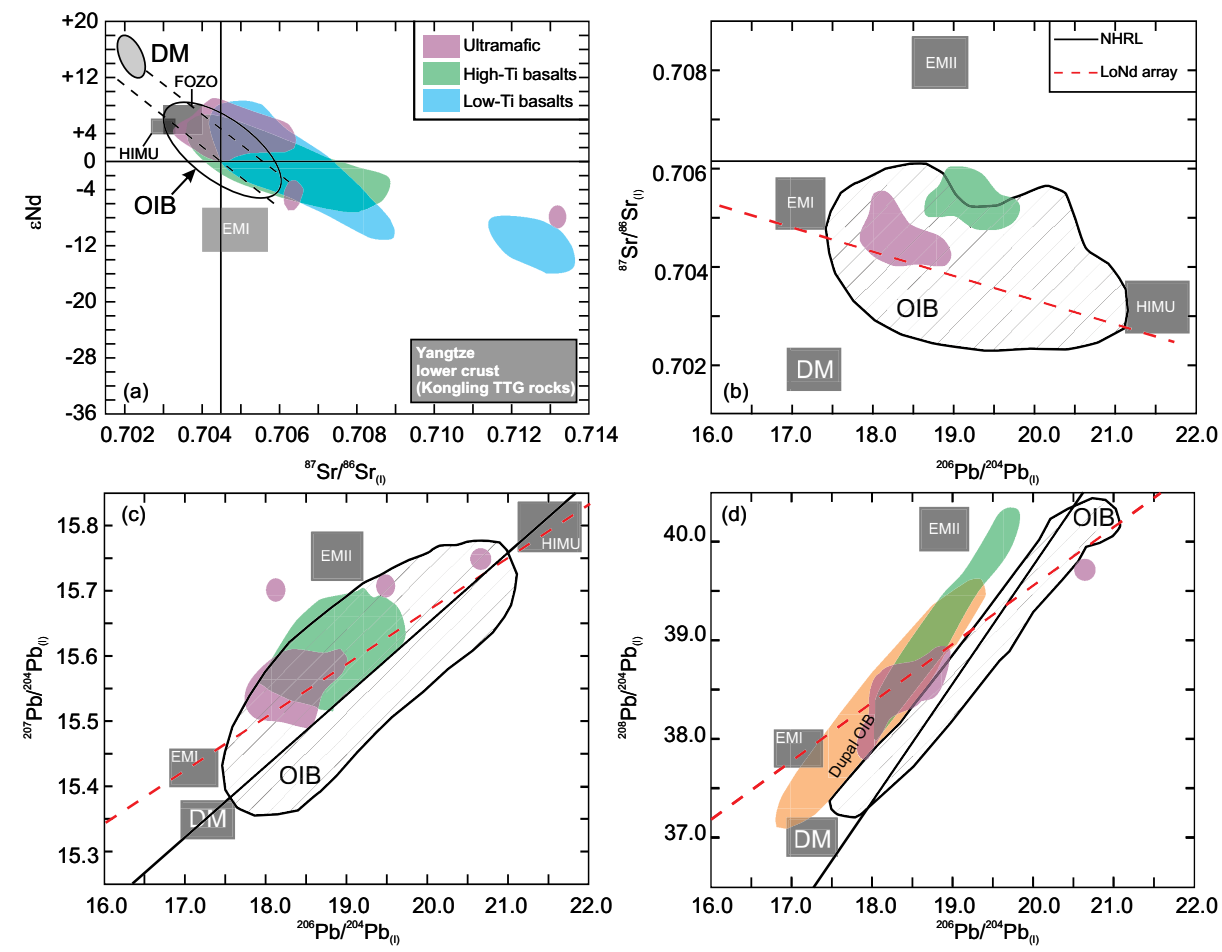

Figure 6. (a) Sr-Nd isotope plot showing the known range of Emeishan ultramafic and mafic volcanic rocks. (b) ${ }^{87} \mathrm{Sr} /{ }^{86} \mathrm{Sr}_{(\mathrm{I})}$ vs. ${ }^{206} \mathrm{~Pb} /{ }^{204} \mathrm{~Pb}$ (I) plot of the Emeishan basalts from Guangxi and ultramafic rocks from Lijiang (western ELIP). (c) ${ }^{207} \mathrm{~Pb} /{ }^{204} \mathrm{~Pb}$ (I) $v$ s. ${ }^{206} \mathrm{~Pb} /{ }^{204} \mathrm{~Pb}$ (I) of the Emeishan basalts from Guangxi and ultramafic rocks from Lijiang (western ELIP). (d) ${ }^{208} \mathrm{~Pb} /{ }^{204} \mathrm{~Pb}$ (I) $v{ }^{\mathrm{vs}}{ }^{206} \mathrm{~Pb} /{ }^{204} \mathrm{~Pb}$ (I) of the Emeishan basalts from Guangxi and ultramafic rocks from Lijiang (western ELIP). EMI and HIMU range taken from Zindler and Hart (1986). GLOSS (global subducting sediment) values taken from Plank and Langmuir (1998) and Chauvel et al. (2008). FOZO range taken from Hart et al. (1992) and Campbell (2007). The range of Yangtze Block lower crust rock compositions taken from Wang et al. (2007). $\mathrm{EMI}=$ enriched mantle $\mathrm{I}, \mathrm{FOZO}=$ focal zone component, HIMU $=$ high $\mu$ $[\mu=((\mathrm{U}+\mathrm{Th}) / \mathrm{Pb})$ reservoir $]$.

alternative ideas have been presented (Utskins Peate and Bryan 2008; Sun et al. 2010; Ali et al. 2010; Wang et al. 2014). The evidence against uplift is twofold: 1) carbonate platform collapse is documented with deep water facies such as radiolarian chert and submarine fans (Sun et al. 2010; Ali et al. 2010; Wang et al. 2014), and 2) that the flood basalts were emplaced at sealevel (i.e. pillow basalt erupted after subaerial basalt) and that previously interpreted alluvial fan sedimentary rocks are actually hydromagmatic deposits (Utskins Peate and Bryan 2008; Wang et al. 2014). The core of the debate is focused on whether the geological evidence (i.e. alluvial fan sediments vs. hydromagmatic deposits; presence of mid-eruption pillow basalts) presented by He et al. (2003, 2007) is actually documenting uplift, not whether the ELIP is or is not mantle plume-derived.

\section{Effect on the Late Permian Ecosystem}

Some mass extinctions are coeval with the eruption of flood basalt (Courtillot et al. 1999; Wignall 2005; White and Saunders 2005). In many cases there is compelling evidence to link specific volcanic episodes to biological crises; however, there are many large igneous provinces (e.g. Tarim, Panjal, Karoo, Ethiopia, Columbia River) that are not contemporaneous with ecosystem collapse. The basic premise is that due to rapidly emplaced basaltic magma, dramatic climatic changes occur at a pace which is faster than the ability of an ecosystem to adapt (Wignall 2005).

Compared to the end-Permian mass extinction, the end-Guadalupian mass extinction $(\sim 260 \mathrm{Ma})$ affected fewer genera but was contemporaneous with the earliest eruption of the Emeishan flood basalts, and as a consequence is considered to have been the cause of, or at least contributed to, the decline in biota at that time (Zhou et al. 2002a; Wignall 2005; He et al. 2007; Retallack and Jahren 2008; Ganino and Arndt 2009). If atmospheric composition is to be affected by magmatism then emplacement rates have to be high. It is suggested that degassing of carbonate-rich country rocks and a rapid (i.e. $<2$ m.y.) emplacement rate was sufficient to induce climate change or at least affect marine chemistry to the point where some genera would be vulnerable and die out (Ganino and Arndt 2009; Shellnutt et al. 2012). It is possible that the ELIP either directly caused or accelerated the end-Guadalupian mass extinction; however, there are larger eruptions of flood basalt during the early Permian which did not affect global ecosystems (e.g. Tarim and Panjal LIPs).

\section{MINERAL DEPOSITS OF THE ELIP}

\section{Ni-Cu-Sulphide and PGE Deposits}

The magmatic sulphide deposits are concentrated within ultramafic and/or mafic intrusive rocks and are found throughout the entire ELIP. The deposits contain variable proportions of $\mathrm{Ni}, \mathrm{Cu}$ and platinum group elements (PGE) within sulphide minerals or platinum group minerals (Zhong et al. 2002; Song et al. 2005; Wang et al. 2011). The propensity of sulphide and/or PGE deposits to form is suggested to be linked with the type (i.e. 'low-Ti') of parental magma (Song et al. 2009; Zhou et al. 2008; Wang et al. 2011). Song et al. (2005) grouped the sulphide and PGE deposits into four genetic types based on inferred petrogenetic processes, and host rock and mineral associations. The four types of deposits are: 1) Ni-Cu-(PGE) by in situ sulphide segregation, 2) PGEenriched layers within layered intrusions, 3) Ni-Cu sulphide related to sulphide-bearing mush, and 4) PGE sulphide ores in ultramafic rocks. Native $\mathrm{Cu}$ and $\mathrm{Au}$ deposits have also been identified but they appear to be related to post-ELIP hydrothermal processes. 


\section{Plume induced uplift and doming}

(a)
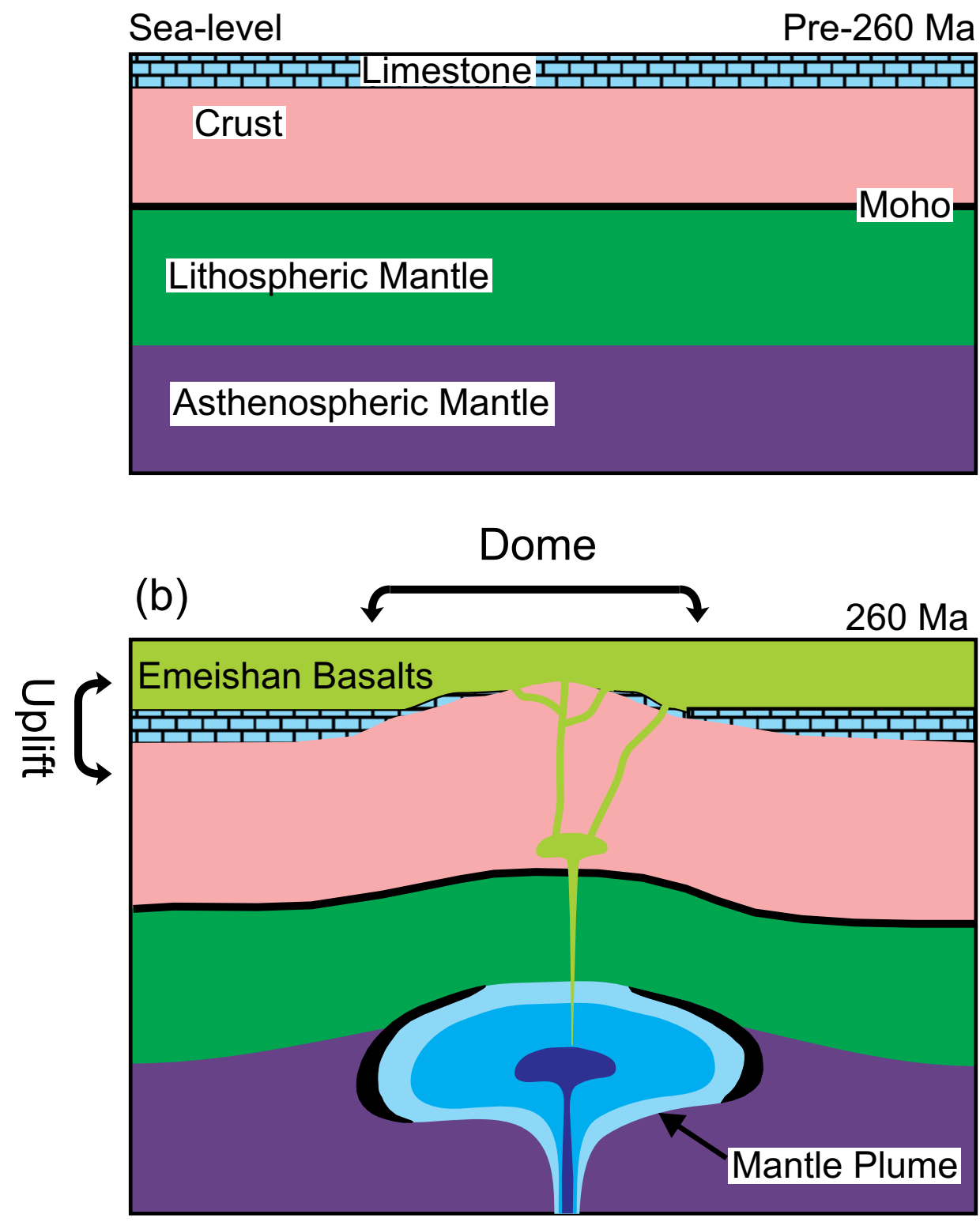

Figure 7. Schematic model of uplift and doming of the crust due to the arrival of the Emeishan mantle plume.

\section{Fe-Ti-V Oxide-Ore Deposits}

There are at least five world-class magmatic oxide deposits within the Panxi region of the inner zone, at least three of which are spatially and temporally associated with alkaline granitoid rocks. Zhou et al. (2005) reported that $\sim 7 \%$ and $\sim 35 \%$ of global production of $\mathrm{V}$ and $\mathrm{Ti}$, respectively, is from China with most of the metals originating from the layered gabbroic complexes of the ELIP. The formation of the layered intrusions and their ore deposits is a highly debated issue. For instance, some consider the gabbro ore bodies to be a separate magma system from the neighbouring silicic plutons, whereas others suggest they are part of the same intrusion (Zhong et al. 2009, 2011; Shellnutt et al. 2011a). Furthermore, the formation of the actual ore deposits is debated and may involve a number of magmatic processes such as silicate immiscibility, fractional crystallization and fluxing of $\mathrm{CO}_{2}$-rich fluids (Zhou et al. 2005, 2013; Zhang et al. 2009; Pang et al. 2010, 2013; Shellnutt et al. 2011a, b; Ganino et al. 2013).
The parental liquids of the oxide deposits are considered to be 'high-Ti' Emeishan basalt. It is thought that the gabbro bodies are derived from 'high-Ti' Emeishan basalt because of the evolved compositions of the olivine (e.g. $\mathrm{FO}_{<82}$ ) and clinopyroxene (e.g. $\mathrm{Mg} \#<80$ ) and the trace element budget (i.e. incompatible element enrichment in silicic plutons). There is evidence for open system behaviour (i.e. multiple magma pulses) and internal redistribution (i.e. mineral chemistry variation) of crystals but the overall process which affected the magma system was crystallization and the consequences of an evolving magma. The ideas on silicate immiscibility are difficult to reconcile in the formation of the oxide ore deposit because the trace element budget (i.e. depletion of the large ion lithophile and high field strength elements) of the layered gabbro bodies is not sufficiently accounted for unless a residual silicic liquid is considered (Pang et al. 2010). A candidate for the residual liquid is the neighbouring peralkaline granitic rocks (Shellnutt et al. 2011a). The hypothesis is that a basaltic parental magma, as represented by a 'high-Ti' Emeishan basalt, is injected in the shallow crust and crystallizes olivine, plagioclase and clinopyroxene. Large quantities of titanomagnetite will crystallize as soon as the magmatic conditions allow (i.e. early or later) but the net result will be that the residual liquid composition becomes more silicic (Shellnutt et al. 2011a).

\section{TECTONOMAGMATIC SYNTHESIS OF THE ELIP}

A unifying theory of the formation of the ELIP is a difficult issue to address because there are many different ideas regarding its genesis. This section brings together the main geological and geochemical features of the ELIP in order to constrain its likely tectonomagmatic history.

During the Late Capitanian to Early Wuchiapingian, the Yangtze Block was a stable carbonate platform at tropical latitudes. It is uncertain what the exact topography (i.e. flat or undulatory) of the carbonate platform was but it is possible that some portion of the Yangtze Block was exposed, whereas most of the platform was sub- 

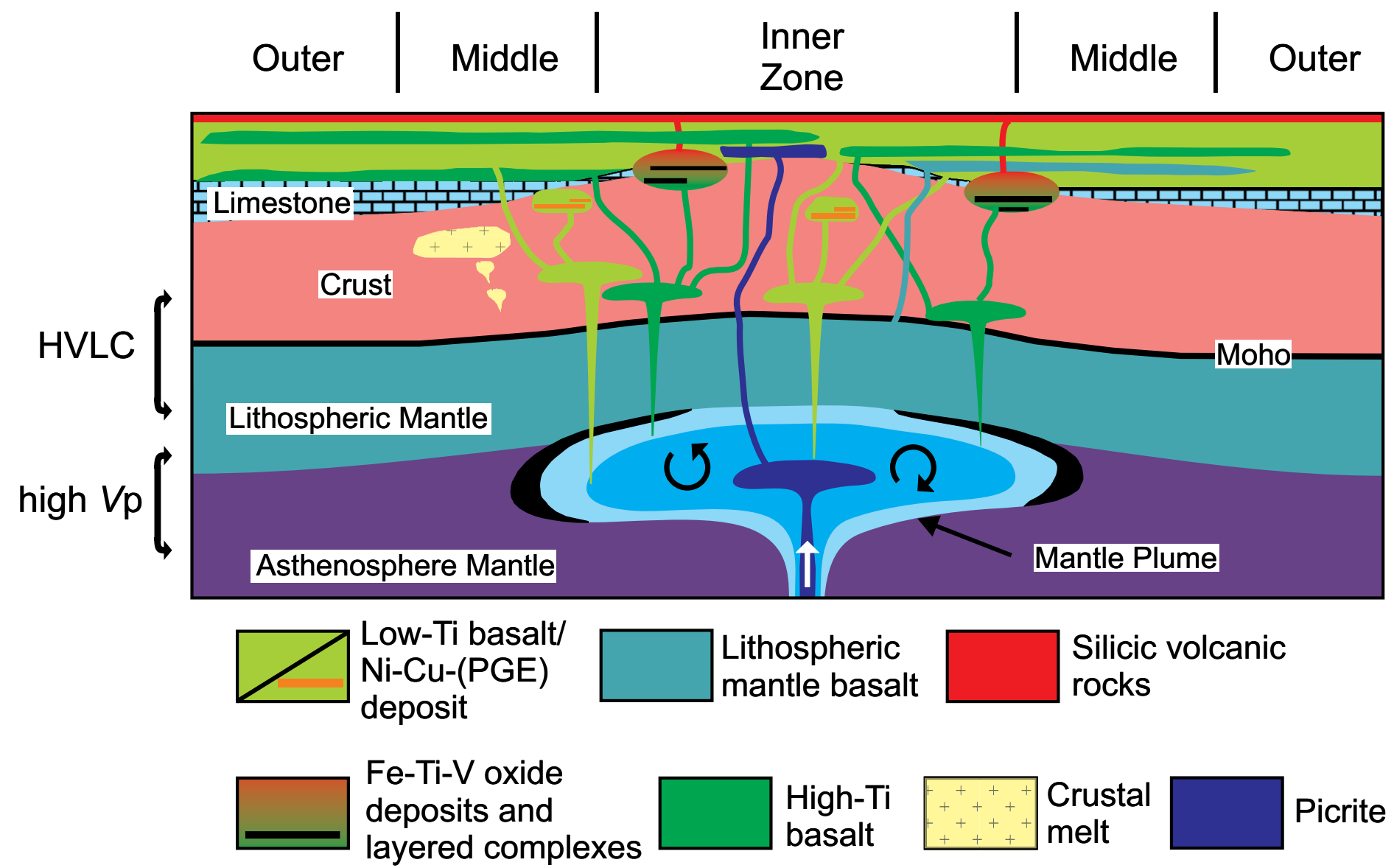

Figure 8. At $260 \mathrm{Ma}$ the ELIP plume head arrives at the base of the lithosphere possibly inducing uplift of the crust and decompressional melting of the plume source. Mafic magmas were injected into the lower crust or upper mantle forming chambers and the HVLC (high velocity lower crust) layer. Some magmas erupted onto the surface, whereas others reached relatively shallow depths and formed the oxide ore-bearing layered intrusions and sulphide ore-bearing intrusions. The continuous injection of mafic magmas likely induced partial melting of the crust which led to the formation of the crust-derived silicic plutons and possible the hybrid silicic plutons.

merged. The volcanic rocks erupted at the same time as several plutonic complexes were emplaced at $\sim 260 \mathrm{Ma}$. Volcanism was short-lived and probably within one magnetic reversal cycle. It is unlikely that ELIP volcanism was continuously active for $\sim 20$ m.y.

The volcanic and the plutonic rocks were likely derived from magmas generated from a mantle plume source, some of which was contaminated by crustal material (Fig. 8). The major and trace elemental and isotope composition of the magmatic rocks indicate that the source was heterogeneous. The subcontinental lithospheric mantle may or may not have been involved but probably cannot be discerned easily due to the isotope heterogeneity of the rocks. Whether uplift and doming of the crust occurred is not a prerequisite. The injection of mafic magmas likely induced partial melting of the
Yangtze Block which led to the formation of some peraluminous to metaluminous silicic rocks, whereas mingling between mafic magmas and crustal melts produced other metaluminous plutonic silicic rocks. Some mafic magmas reached shallow crustal levels (i.e. $<3 \mathrm{~km}$ ) and crystallized to form the cumulate layered mafic-ultramafic complexes, some of which produced the plutonic peralkaline silicic rocks and the Fe-Ti-V oxide deposits (Fig. 8).

The precise cause of the ELIP is uncertain but it could be due to the random formation of a mantle plume related to plate tectonics or due to the plate dynamics of the North ChinaSouth China-Indochina Block amalgamation. Many LIPs are associated with continental break-up and mantle plumes but not all are related to both. The emplacement of the ELIP was within a tensional environment; however, it did not cause the Yangtze Block to split, unlike that of other LIPs (i.e. Central Atlantic Magmatic Province, Karoo).

\section{ACKNOWLEDGEMENTS}

I would like to thank Jean Bédard and an anonymous reviewer for their comments on the manuscript and the editorial handling by Brendan Murphy and type setting by Cindy Murphy. Special thanks to Mei-Fu Zhou, Jason Ali, Sun-Lin Chung, Steve Denyszyn, Clement Ganino, Eero Hanski, BorMing Jahn, George Ma, Kwan-Nang Pang, Liang Qi, Xie-Yan Song, Christina Wang, Kuo-Lung Wang and YiGang Xu for their opinions on all matters related to the ELIP over the years.

\section{REFERENCES}

Ali, J.R., Thompson, G.M., Zhou, Mei-Fu, 
and Song, Xieyan, 2005, Emeishan large igneous province, SW China: Lithos, v. 79, p. 475-489, http://dx.doi.org/10.1016/j.lithos.200 4.09.013.

Ali, J.R., Fitton, J.G., and Herzberg, C., 2010, Emeishan large igneous province (SW China) and the mantleplume up-doming hypothesis: Journal of the Geological Society, v. 167, p. 953-959, http://dx.doi.org/ 10.1144/0016-76492009-129.

Anh, T.V., Pang, K.-N., Chung, S.-L., Lin, H.-M., Hoa, T.T., Anh, T.T., and Yang, H-.J., 2011, The Song Da magmatic suite revisited: A petrologic, geochemical and $\mathrm{Sr}-\mathrm{Nd}$ isotopic study on picrites, flood basalts and silicic volcanic rocks: Journal of Asian Earth Sciences, v. 42, p. 1341-1355, http://dx.doi.org/10.1016/j.jseaes.201 1.07.020.

Bryan, S.E., and Ernst, R.E., 2008, Revised definition of Large Igneous Provinces (LIPs): Earth-Science Reviews, v. 86, p. 175-202, http://dx.doi.org/ 10.1016/j.earscirev.2007.08.008.

Campbell, I.H., 2005, Large igneous provinces and the mantle plume hypothesis: Elements, v. 1, p. 265-269, http://dx.doi.org/10.2113/gselements.1.5.265.

Campbell, I.H., 2007, Testing the plume theory: Chemical Geology, v. 241, p. 153-176, http://dx.doi.org/ 10.1016/j.chemgeo.2007.01.024

Chauvel, C., Lewin, E., Carpenter, M., Arndt, N.T., and Marini, J.-C., 2008, Role of recycled oceanic basalt and sediment in generating the $\mathrm{Hf}-\mathrm{Nd}$ mantle array: Nature Geoscience, v. 1, p. 64-67, http://dx.doi.org/ 10.1038/ngeo.2007.51.

Chung, S.-L., and Jahn, B.-M., 1995 , Plume-lithosphere interaction in generation of the Emeishan flood basalts at the Permian-Triassic boundary: Geology, v. 23, p. 889-892, http://dx.doi.org/10.1130/00917613(1995)023<0889:PLIIGO>2.3.C $\mathrm{O} ; 2$.

Chung, S.-L., Lee, T.-Y., Lo, C.-H., Wang, P.-L., Chen, C.-Y., Yem, N.T., Hoa, T.T., and Genyao, W., 1997, Intraplate extension prior to continental extrusion along the Ailao Shan-Red River shear zone: Geology, v. 25, p. 311-314, http://dx.doi.org/ 10.1130/0091-7613(1997)025 $<0311$ :IEPTCE > 2.3.CO;2.

Coffin, M.F., and Eldholm, O., 1994, Large igneous provinces: Crustal structure, dimensions and external consequences: Reviews in Geophysics, v. 32, p. 1-36, http://dx.doi.org/
10.1029/93RG02508.

Courtillot, V., Jaupart, C., Manighetti, I., Tapponier, P., and Besse, J., 1999, On causal links between flood basalts and continental breakup: Earth and Planetary Science Letters, v. 166, p. 177-195, http:/ /dx.doi.org/ 10.1016/S0012-821X(98)00282-9.

Fan, W., Zhang, C., Wang, Y., Guo, F., and Peng, T., 2008, Geochronology and geochemistry of Permian basalts in western Guangxi Province, southwest China: evidence for plume-lithosphere interaction: Lithos, v. 102, p. 218-236, http://dx.doi.org/10.1016/j.lithos.200 7.09.019.

Ganino, C., and Arndt, N.T., 2009, Climate changes caused by degassing of sediments during the emplacement of large igneous provinces: Geology, v. 37, p. 323-326, http:/ /dx.doi.org/ 10.1130/G25325A.1.

Ganino, C., Harris, C., Arndt, N.T., Prevec, S.A., and Howarth, G.H., 2013, Assimilation of carbonate country rock by the parent magma of the Panzhihua Fe-Ti-V deposit (SW China): Evidence from stable isotopes: Geoscience Frontiers, v. 4, p. 547-554, http://dx.doi.org/10.1016/j.gsf.2012.1 2.006 .

Hanski, E., Walker, R.J., Huhma, H., Polyakov, G.V., Balykin, P.A., Hoa, T.T., and Phuong, N.T., 2004, Origin of the Permian-Triassic komatiites, northwestern Vietnam: Contributions to Mineralogy and Petrology, v. 147, p. 453-469, http:/ /dx.doi.org/ 10.1007/s00410-004-0567-1.

Hanski, E., Kamenetsky, V.S., Luo, Z.-Y., Xu, Y.-G., and Kuzmin, D.V., 2010, Primitive magmas in the Emeishan large igneous province, southwestern China and northern Vietnam: Lithos, v. 119, p. 75-90, http://dx.doi.org/ 10.1016/j.lithos.2010.04.008.

Hart, S.R., Hauri, E.H., Oschmann, L.A., and Whitehead, J.A., 1992, Mantle plumes and entrainment: Isotopic evidence: Science, v. 256, p. 517-520, http://dx.doi.org/10.1126/science.256.5056.517.

He, B., Xu, Y.-G., Chung, S.-L., Xiao, L., and Wang, Y., 2003, Sedimentary evidence for a rapid, kilometer-scale crustal doming prior to the eruption of the Emeishan flood basalts: Earth and Planetary Science Letters, v. 213, p. 391-405, http://dx.doi.org/ 10.1016/S0012-821X(03)00323-6.

He, B., Xu, Y.-G., Huang, X.-L., Luo, Z.-Y., Shi, Y.-R., Yang, O.-J., and Yu S.-Y., 2007, Age and duration of the Emeishan flood volcanism, SW China: Geochemistry and SHRIMP zircon U-Pb dating of silicic ignimbrites, post-volcanic Xuanwei Formation and clay tuff at the Chaotian section: Earth and Planetary Science Letters, v. 255, p. 306-323, http://dx.doi.org/ 10.1016/j.epsl.2006.12.021.

He, Q., Xiao, L., Balta, B., Gao, R., and Chen, J., 2010, Variety and complexity of the Late-Permian Emeishan basalts: Reappraisal of plume-lithosphere interaction processes: Lithos, v. 119, p. 91-107, http://dx.doi.org/ 10.1016/j.lithos.2010.07.020.

Hou Z., Lu J., and Lin S., 2006, Heterogeneity of a plume axis: bulk-rock geochemical evidence from picrites and basalts in the Emei large igneous province, southwest China: International Geology Review, v. 48, p. 1087-1112, http://dx.doi.org/ 10.2747/0020-6814.48.12.1087.

Kamenetsky, V.S., Chung, S.-L., Kamenetsky, M.B., and Kuzmin, D.V., 2012, Picrites from the Emeishan large igneous province, SW China: a compositional continuum in primitive magmas and their respective mantle sources: Journal of Petrology, v. 53, p. 2095-2113, http://dx.doi.org/ 10.1093/petrology/egs045.

Lai, S., Qin, J., Li, Y., Li, S., and Santosh, M., 2012, Permian high Ti/Y basalt from the eastern part of the Emeishan large igneous province, southwestern China: Petrogenesis and tectonic implications: Journal of Asian Earth Sciences, v. 47, p. 216-230, http://dx.doi.org/10.1016/j.jseaes.201 1.07.010.

Li, C., Tao, Y., Qi, L., and Ripley, E.M., 2012, Controls on PGE fractionation in the Emeishan picrites and basalts: Constraints from integrated lithophile-siderophile elements and Sr-Nd isotopes: Geochimica et Cosmochimica Acta, v. 90, p. 12-32, http://dx.doi.org/10.1016/j.gca.2012. 04.046.

Li, J., Xu, J.-F., Suzuki, K., He, B., Xu, YG., and Ren, Z.-Y., 2010, Os, Nd and $\mathrm{Sr}$ isotope and trace element geochemistry of the Muli picrites: Insights into the mantle source of the Emeishan large igneous province: Lithos, v. 119, p. 108-122, http://dx.doi.org/10.1016/j.lithos.201 0.06.002.

Pang, K.-N., Zhou, M.-F., Qi, L., Shellnutt, G., Wang. C.Y., and Zhao, D., 2010, Flood basalt-related Fe-Ti oxide deposits in the Emeishan large igneous province, SW China: Lithos, v. 119, p. 123-136, http://dx.doi.org/ 10.1016/j.lithos.2010.06.003.

Pang, K.-N., Zhou, M.-F., Qi, L., Chung, 
S.-L., Chu, C.-H., and Lee, H.-Y., 2013, Petrology and geochemistry at the Lower zone-Middle zone transition of the Panzhihua intrusion, SW China: Implications for differentiation and oxide ore genesis: Geoscience Frontiers, v. 4, p. 517-533, http://dx.doi.org/10.1016/j.gsf.2013.0 1.006.

Plank, T., and Langmuir, C.H., 1998, The chemical composition of subducting sediment and its consequences for the crust and mantle: Chemical Geology, v. 145, p. 325-394, http://dx.doi.org/ 10.1016/S0009-2541(97)00150-2.

Qi, H., Xiao, L., Balta, B., Gao, R., and Chen, J., 2010, Variety and complexity of the Late-Permian Emeishan basalts: Reappraisal of plume-lithosphere interaction processes: Lithos, v. 119, p. 91-107, http://dx.doi.org/ 10.1016/j.lithos.2010.07.020.

Retallack, G.J., and Jahren, A.H., 2008, Methane release from igneous intrusion of coal during Late Permian extinction events: The Journal of Geology, v. 116, p. 1-20, http://dx.doi.org/10.1086/524120.

Rudnick, R.L., and Gao, S., 2003, Composition of the continental crust, in Rudnick, R.L., ed., Treatise on Geochemistry: The Crust, volume 3: Elsevier, p. 1-64, http://dx.doi.org/10.1016/B008-043751-6/03016-4.

Shellnutt, J.G., 2014, The Emeishan large igneous province: A synthesis: Geoscience Frontiers, v. 5, p. 369-394, http://dx.doi.org/10.1016/j.gsf.2013.0 7.003 .

Shellnutt, J.G., and Jahn, B.-M., 2011, Origin of Late Permian Emeishan basaltic rocks from the Panxi region (SW China): Implications for the Ticlassification and spatial-compositional distribution of the Emeishan flood basalts: Journal of Volcanology and Geothermal Research, v. 199, p. 85-95, http://dx.doi.org/ 10.1016/j.jvolgeores.2010.10.009.

Shellnutt, J.G., and Zhou, M.-F., 2007, Permian peralkaline, peraluminous and metaluminous A-type granites in the Panxi district, SW China: Their relationship to the Emeishan mantle plume: Chemical Geology, v. 243, p. 286-316, http://dx.doi.org/ 10.1016/j.chemgeo.2007.05.022.

Shellnutt, J.G., Wang, K.-L., Zellmer, G.F., Iizuka, Y., Jahn, B.-M., Pang, K.-N., Qi, L. and Zhou, M.-F., 2011a, Three Fe-Ti oxide ore-bearing gabbro-granitoid complexes in the Panxi region of the Permian Emeishan large igneous province, SW China: American Journal of Science, v. 311, p. 773-812, http:/ /dx.doi.org/10.2475/

09.2011.02.

Shellnutt, J.G., Jahn, B.-M., and Zhou, M.F., 2011b, Crustally-derived granites in the Panzhihua region, SW China: implications for felsic magmatism in the Emeishan large igneous province: Lithos, v. 123, p. 145-157, http://dx.doi.org/10.1016/j.lithos.201 0.10.016.

Shellnutt, J.G., Denyszyn, S., and Mundil, R., 2012, Precise age determination of mafic and felsic intrusive rocks from the Permian Emeishan large igneous province (SW China): Gondwana Research, v. 22, p. 118-126, http://dx.doi.org/10.1016/j.gr.2011.1 0.009 .

Song, X.-Y., Zhou, M.-F., Hou, Z.-Q., Cao, Z.-M., Wang, Y.-L., and Li, Y., 2001, Geochemical constraints on the mantle source of the upper Permian Emeishan continental flood basalts, southwestern China: International Geology Review, v. 43, p. 213-225, http://dx.doi.org/10.1080/002068101 09465009.

Song, X.-Y., Zhong, H., Tao, Y., and Zhou, M.-F., 2005, Magmatic sulphide deposits in the Permian Emeishan large igneous province, SW China, in Mao, J. and Bierlein, F.P., eds., Mineral Deposit Research: Meeting the Global Challenge. Proceedings of the Eighth Biennial SGA Meeting, Beijing, Chapter 4-29, p. 465-467.

Song, X.-Y., Qi, H.-W., Robinson, P.T., Zhou, M.-F., Cao, Z.-M., and Chen, L.-M., 2008, Melting of the subcontinental lithospheric mantle by the Emeishan mantle plume; evidence from the basal alkaline basalts in Dongchuan, Yunnan, southwestern China: Lithos, v. 100, p. 93-111, http://dx.doi.org/10.1016/j.lithos.200 7.06.023.

Song, X.-Y., Keays, R.R., Xiao, L., Qi, H.W., and Ihlenfeld, C., 2009, Platinumgroup element geochemistry of the continental flood basalts in the central Emeishan large igneous province, SW China: Chemical Geology, v. 262, p. 246-261, http://dx.doi.org/ 10.1016/j.chemgeo.2009.01.021.

Sun, S.-s., and McDonough, W.F., 1989, Chemical and isotopic systematics of oceanic basalts: implications for mantle composition and processes, in Saunders, A.D., and Norry, M.J., eds., Magmatism in the Ocean Basins: Geological Society, London, Special Publications, v. 42, p. 313-435, http://dx.doi.org/10.1144/GSL.SP.19 89.042.01.19.

Sun, Y., Lai, X., Wignall, P.B., Widdowson,
M., Ali, J.R., Jiang, H., Wang, W., Yan, C., Bond, D.P.G., and Védrine, S., 2010, Dating the onset and nature of the middle Permian Emeishan large igneous province eruptions in SW China using conodont biostratigraphy and its bearing on mantle plume uplift models: Lithos, v. 119, p. 20-33, http://dx.doi.org/10.1016/j.lithos.201 0.05.012.

Utskins Peate, I., and Bryan, S.E., 2008, Re-evaluating plume induced uplift in the Emeishan large igneous province: Nature Geoscience, v. 1, p. 625-629, http://dx.doi.org/10.1038/ngeo281.

Wang, C.Y., Zhou, M.-F., and Qi, L., 2007, Permian flood basalts and mafic intrusions in the Jinping (SW China)-Song $\mathrm{Da}$ (northern Vietnam) district: Mantle sources, crustal contamination and sulfide segregation: Chemical Geology, v. 243, p. 317-343, http://dx.doi.org/ 10.1016/j.chemgeo.2007.05.017.

Wang, C.Y., Zhou, M.-F., and Qi, L., 2011, Chalcophile element geochemistry and petrogenesis of high-Ti and low-Ti magmas in the Permian Emeishan large igneous province, SW China: Contributions to Mineralogy and Petrology, v. 161, p. 237-254, http://dx.doi.org/10.1007/s00410010-0529-8.

Wang, Y., Luo, Z., Wu, P., Chen, L., and Hao, J., 2014, A new interpretation of the sedimentary environment before and during eruption of the Emeishan LIP, Southwest China: International Geology Review, v. 56, p. 1295-1313, http://dx.doi.org/10.1080/00206814. 2014.936056.

White, R.V., and Saunders, A.D., 2005, Volcanism, impact and mass extinctions: incredible or coincidences?: Lithos, v. 79, p. 299-316, http://dx.doi.org/ 10.1016/j.lithos.2004.09.016.

Wignall, P., 2005, The link between large igneous province eruptions and mass extinctions: Elements, v. 1, p. 293-297, http://dx.doi.org/ 10.2113/gselements.1.5.293.

Winchester, J.A., and Floyd, P.A., 1977, Geochemical discrimination of different magma series and their differentiation products using immobile elements: Chemical Geology, v. 20, p. 325-343, http:/ /dx.doi.org/ 10.1016/0009-2541(77)90057-2.

Xiao, L., Xu, Y.G., Mei, H.J., Zheng, Y.F., He, B., and Pirajno, F., 2004, Distinct mantle sources of low-Ti and high-Ti basalts from the western Emeishan large igneous province, SW China: implications for plume-lithosphere interaction: Earth and Planetary Science Letters, v. 228, p. 525-546, 
http://dx.doi.org/10.1016/j.epsl.2004. 10.002.

Xu, Y., Chung, S.-L., Jahn, B.-M., and Wu, G., 2001, Petrologic and geochemical constraints on the petrogenesis of Permian-Triassic Emeishan flood basalts in southwestern China: Lithos, v. 58, p. 145-168, http://dx.doi.org/ 10.1016/S0024-4937(01)00055-X.

Xu, Y.-G., He, B., Chung, S.-L., Menzies, M.A., and Frey, F.A., 2004, Geologic, geochemical, and geophysical consequences of plume involvement in the Emeishan flood-basalt province: Geology, v. 32, p. 917-920, http://dx.doi.org/10.1130/G20602.1.

Xu, Y.-G., Luo, Z.-Y., Huang, X.-L., He, B., Xiao, L., Xie, L.-W., and Shi, Y.-R., 2008, Zircon U-Pb and Hf isotope constraints on crustal melting associated with the Emeishan mantle plume: Geochimica et Cosmochimica Acta, v. 72, p. 3084-3104, http://dx.doi.org/ 10.1016/j.gca.2008.04.019.

Xu, Y.-G., Chung, S.-L., Shao, H., and He, B., 2010, Silicic magmas form the Emeishan large igneous province, southwest China: Petrogenesis and their link with the end-Guadalupian biological crisis: Lithos, v. 119, p. 47-60, http://dx.doi.org/ 10.1016/j.lithos.2010.04.013.

Zhang, Z., Mahoney, J.J., Mao, J., and Wang, F., 2006, Geochemistry of picritic and associated basalt flows of the western Emeishan flood basalt province, China: Journal of Petrology, v. 47, p. 1997-2019, http://dx.doi.org/10.1093/petrology/eg1034.

Zhang, Z., Mao, J., Saunders, A.D., Ai, Y., Li, Y., and Zhao, L., 2009, Petrogenetic modeling of three mafic-ultramafic layered intrusions in the Emeishan large igneous province, SW China, based on isotopic and bulk chemical constraints: Lithos, v. 113, p. 369-392, http://dx.doi.org/10.1016/j.lithos.200 9.04.023.

Zheng, L., Yang, Z., Tong, Y., and Yuan, W., 2010, Magnetostratigraphic constraints on two-stage eruptions of the Emeishan continental flood basalts: Geochemistry, Geophysics, Geosystems, v. 11, Q12014, http://dx.doi.org/10.1029/2010GC00 3267.

Zhong, H., Zhou, X.-H., Zhou, M.-F., Sun, M., and Liu, B.-G., 2002, Platinumgroup element geochemistry of the Hongge Fe-V-Ti deposit in the Pan-Xi area, southwestern China: Mineralium Deposita, v. 37, p. 226-239, http://dx.doi.org/10.1007/s00126001-0220-0.
Zhong, H., Zhu, W.-G., Hu, R.-Z., Xie, L.W., He. D.-F., Liu. F., and Chu, Z.-Y., 2009, Zircon U-Pb age and

$\mathrm{Sr}-\mathrm{Nd}-\mathrm{Hf}$ isotope geochemistry of the Panzhihua A-type syenitic intrusion in the Emeishan large igneous province, southwest China and implications for growth of juvenile crust: Lithos, v. 110, p. 109-128, http://dx.doi.org/10.1016/j.lithos.200 8.12.006.

Zhong, H., Campbell, I.H., Zhu, W.-G., Allen, C.M., Hu, R.-Z., Xie, L.-W., and He, D.-F., 2011, Timing and source constraints on the relationship between mafic and felsic intrusions in the Emeishan large igneous province: Geochimica et Cosmochimica Acta, v. 75, p. 1374-1395, http://dx.doi.org/ 10.1016/j.gca.2010.12.016.

Zhou, M.-F., Malpas, J. Song, X.-Y., Robinson, P.T., Sun, M., Kennedy, A.K., Lesher, C.M., and Keays, R.R., 2002a, A temporal link between the Emeishan large igneous province (SW China) and the end-Guadalupian mass extinction: Earth and Planetary Science Letters, v. 196, p. 113-122, http://dx.doi.org/10.1016/S0012821X(01)00608-2.

Zhou, M.-F., Yan, D.P., Kennedy, A.K., Li, Y., and Ding, J., 2002b, SHRIMP $\mathrm{U}-\mathrm{Pb}$ zircon geochronological and geochemical evidence for Neoproterozoic arc-magmatism along the western margin of the Yangtze block, South China: Earth and Planetary Science Letters 196, p. 51-67, http://dx.doi.org/10.1016/S0012821X(01)00595-7.

Zhou, M.-F., Robinson, P.T., Lesher, C.M., Keays, R.R., Zhang, C.-J., and Malpas, J., 2005, Geochemistry, petrogenesis and metallogenesis of the Panzhihua gabbroic layered intrusion and associated Fe-Ti-V oxide deposits, Sichuan Province, SW China: Journal of Petrology, v. 46, p. 2253-2280, http://dx.doi.org/10.1093/petrology/egi054.

Zhou, M.-F., Arndt, N.T., Malpas, J., Wang, C.Y., and Kennedy, A.K., 2008, Two magma series and associated ore deposit types in the Permian Emeishan large igneous province, SW China: Lithos, v. 103, p. 352-368, http://dx.doi.org/10.1016/j.lithos.200 7.10.006.

Zhou, M.-F., Chen, W.T., Wang, C.Y., Prevec, S.A., Liu, P.P., and Howarth, G.H., 2013, Two stages of immiscible liquid separation in the formation of Panzhihua-type Fe-Ti-V oxide deposits, SW China: Geoscience Frontiers, v. 4, p. 481-502, http://dx.doi.org/10.1016/j.gsf.2013.0 4.006.

Zindler, A., and Hart, S., 1986, Chemical geodynamics: Annual Review of Earth and Planetary Sciences, v. 14, p. 493-571, http://dx.doi.org/ 10.1146/annurev.ea.14.050186.002425.

\author{
Received April 2014 \\ Accepted as Revised October 2014 \\ First published on the web \\ November 2014
}

